Agenda, Volume 3, Number 1, 1996, pages 3-30

\title{
Public Policy and National Saving
}

\section{Vince FitzGerald}
70 propose that policy should seek to influence the level of saving presupposes that there is a 'right' level of saving from which, without the intervention, we would diverge.

In an ideal world with no distortions in capital markets or to the terms on which households make intertemporal choices, households would freely choose an allocation of their income between present and future consumption and live with the outcome. The level of saving that would emerge would be that at which households' willingness to trade off present consumption against increased future consumption equates to what their savings, invested in the economy, can actually deliver in real returns. The level of saving would then be 'right' by definition and of no concern in itself to public policy, as nicely articulated by Milton Friedman (1990:53):

The right level — at least to a first approximation - is the level that would emerge if all the separate households were free to divide their income between current and future consumption in accordance with their own values, provided only that the terms on which they could do so were not distorted and did not impose uncompensated costs or benefits on other households ...

However, the caveats in Friedman's definition suggest that, in the real world as opposed to an ideal world, sub-optimal saving may emerge. One reason for this is that our tax and social security and welfare systems significantly distort the terms on which households make intertemporal choices. These distortions push savers' net returns below the full gains from invested savings that the real economy can deliver, so biasing choices towards present consumption. Another reason (which is really a particular case of the foregoing point) is that it is open to some households individually to impose uncompensated costs on other houseliolds. In particular, our social security system has allowed some households that could readily make greater provision for their own retirement to choose not to do so, and to impose burdens on households in the future, including many that may well be no better off than themselves. Through government, present households collectively can also transfer the costs of present public consumption to future households that have no say in the matter. Either way, there is a bias away from saving and towards present consumption. 


\section{Government's Involvement in Low Saving}

Some of the reasons for sub-optimal saving, such as domestic and international capital market impediments, cannot be attributed to government. But the operations of government itself clearly are deeply involved. Government affects the level of saving undertaken by the community in a number of ways. The most direct way is the least discussed: government's own saving or dissaving. This is by definition its operating surplus or deficit on its own recurrent operations, as distinct from the usually quoted total (cash) budget deficit, which includes capital transactions. If government runs persisting recurrent or operating deficits (dissaves), it creates an intergenerational equity issue in Friedman's terms, because it delivers benefits to the community now while leaving liabilities to future households with no corresponding assets to compensate them. Moreover, government progressively loses fiscal capacity to deal with future contingencies.

As the National Saving report (FitzGerald, 1993) detailed, secular deterioration of government saving, predominantly at Commonwealth level, has been the major contributor to the decline in Australia's national saving over the past 20 years. ${ }^{1}$ Andersen and Gruen point out that this is true of nearly all of the OECD countries (plus Switzerland) that they examine which show large declines in national saving. Australia is one of only two of the countries they examine for which the rate of household saving fell as well (France being the other). They speculate whether in these two countries household saving is particularly sensitive to the different cyclical conditions of the 1960s and the 1990s or disincentives to household saving have become stronger' (Andersen \& Gruen, 1995:14). Since the decline in Australian household saving has been apparent through a number of cycles whose patterns do not slow a consistent progression, the latter explanation (stronger disincentives) seems more likely.

\section{Is There a 'Right' or Ideal Policy on Saving?}

The above considerations point to a 'first best' or 'ideal' set of policies that might be prescribed to return saving to the 'right' level. First, consumption spending should be taxed rather than income (and tax-induced disparities in the net rates of return from savings in different forms should be eliminated). Second, opportunities for the 'moral hazard' behaviour discussed above - the opportunities for some households to choose to act so as to qualify for benefits at a cost to other (particularly future) households ${ }^{2}$ - should be eliminated from the social security and welfare systems. Third, 'fiscal responsibility' arrangements should be

\footnotetext{
${ }^{1}$ Sims (1995) has recently documented the Australian decline in public saving, and its consequences, in more detail.

2 The opportunities for such behaviour are obvious. Concrete evidence of it actually happening exists in the changing retirement behaviour of older males, who are increasingly able to arrange their affairs with taxpayer support so as to retire early and go on to receive the age pension (see Edey et al., 1991:23-5); and in the way that almost all households approaching pensionable age are able to reancange their assets so as to avoid the age pension assets test (Freebain et al., 1989:173).
} 
implemented under which governments bring to account the full accruing costs of their current operations and which commit them to operating (on average) in balance, or even in surplus, on that basis.

There is an obvious case for running surpluses on recurrent budget when debt has become excessive. There are also arguments for it as an ongoing policy, as canvassed by FitzGerald (1993:73-5). These include the fact that many public investments benefit predominantly the present generation, so that it would be inequitable to finance them by leaving disproportionate debt servicing burdens for future generations. In this regard, it is sometimes argued that leaving such burdens is justified by the likelihood that the next generation will still be better off; but I do not believe we cau either presume that that is so or use it as a pretext for imposing burdens on a future generation which has no say in the matter. Note also that where governments do not operate full accrual accounting, the budget balance is typically significantly overstated (by the omission of depreciation, for example), so that a surplus as measured is needed to replicate balance on a full accruals basis.

We might or might not be able to predict the particular level of saving that would flow under fiscal responsibility policies. But, in the vein of the earlier discussion, it would be close to 'right' and not of concern in itself, regardless of how it compared with past or international levels. The problem is that such policies in their pure form do not seem to be achievable (or necessarily desirable) in the real world.

\section{Why 'First Best' Policies May be Out of Reach}

A consumption tax. Two rounds of intensive debate on a consumption tax have occurred in Australia over the past decade: once in the context of the 1985 Tax Summit and again in the context of the Liberal-National Coalition's Fightback! policies put forward for the 1993 election. The politics of overtly introducing a new consumption tax are obviously now difficult, although partial moves in that direction (such as by incrementally extending the wholesale sales tax base) may not be as difficult.

Any major shift from income to consumption taxation using indirect taxes, such as a value-added tax (VAT) or a goods and services tax (GST), also raises difficult equity and other issues. Even if some basic commodities, such as food, were exempted, a VAT or GST would (on its own) be less progressive than what it replaced; and it would potentially disadvantage groups (such as the retired) whose consumption spending may exceed their income. Compensation of such groups becomes an important issue.

An alternative that can avoid at least the first of those problems is a direct expenditure tax, the case for which was made eloquently by the Meade Committee (Institute for Fiscal Studies, 1978). As the Meade Committee lucidly argued, a direct expenditure tax regime is ideal from the point of view of setting the right incentives for saving decisions, since the after-tax return from a dollar saved is equal to the full return on the underlying investunents in the real economy, thus eliminating the anti-saving distortion. Under this regime, saving is exempt from tax when un- 
dertaken and while returns are accumulating. As saving is taxed at full marginal rates when withdrawn to spend, this system can, unlike a VAT or GST system, address equity issues by being as progressive as desired.

Unfortunately, replacement of our income tax system with the full-scale Meade scheme presents what have so far seemed to be insuperable transitional problems (such as quarantining 'old' savings and protecting those living on them, managing the initial deferral of revenues, preventing indefinite deferral). In practical terms, we are probably left to look at restricted alternatives to the full scheme, such as expenditure-tax-type treatment for, say, saving committed for at least three or five years, consistent with what appears to be the typical lorizon of saving for major lifecycle purposes other than retirement (five or seven or more years). ${ }^{3}$

Welfare reform. Welfare reform to eliminate 'moral hazard' opportunities - or, equivalently, as Cox (1994) suggests, to restrict programs (like the age pension) that most directly substitute for private saving - also presents difficulties. There is obviously considerable scope for reform to Australia's system, to cut back middle-class welfare and churning; but a substantial social safety net appears to have strong community support on equity and social-cohesion grounds. It seems clear that the community is willing to extend significant safety-net support to those in need, even if their need might be regarded as 'their own fault' in the sense that they could have self-provided but did not. Policy changes that respect these community attitudes may again not achieve outcomes that are 'ideal' in terms of their impact on saving.

Fiscal responsibility. In respect of governunent's own saving, it is possible to be more sanguine about approximating 'first best' policies. Few governments would accept very rigid constraints on their fiscal flexibility regardless of economic conditions or contingencies, and we might expect most governments to seek to avoid restrictions on their ability to spend now at the future's expense. Yet some governments, like New Zealand's, have imposed fiscal disciplines on themselves that tend to ensure that they operate transparently and do not run persistent recurrent deficits. New Zealand's policies also reflect an understanding that it matters significantly whether a given deficit outcome is achieved by expenditure restraint or by taxation, given the high deadweight costs of marginal taxation. ${ }^{4}$ At the federal level in Australia, however, such explicit fiscal responsibility policies seem some way off.

\footnotetext{
${ }^{3}$ Even if well selected on such life-cycle considerations, any minimum term will tend to distort choices between horizons that are close to that term. However, houseliold access to credit should smooth that distortion, leaving overall incentives to save or to consume now rather than in future years much less distorted than under an income tax regime. Features such as a minimum term are essentially practical devices to manage the trausition to a regime where a substantially langer part of financial saving receives expenditure taxation treatment. They could be phased out (or modified to different values) in the longer term.

${ }^{4}$ Diewert and Lawrence (1995:32) argue that 'the overriding Ifiscall priority should be to reduce government expenditure and public-debt levels, and to pave the way for sustainable reductions in taxation levels'. They put the economic cost of labour taxation at the margin in New Zealand at 18 per
} 


\section{What Should Real-World Savings Policies Aim to Do?}

A tentative conclusion from the discussion so far is that it would be neither readily feasible nor supported by the majority in the community to implement a pure 'first best' policy that would make achievement of the 'right' level of saving automatic. That leaves the possibility of a saving outcome emerging that is sub-optimal in terms of:

- household choices distorted against saving;

- opemness to 'moral hazard' behaviour especially with regard to the age pension, and associated intergenerational inequity;

- deterioration of government finances; and

- as a result of all of these, significant impairment of our ability to achieve on a sustained basis the higher rates of economic growth, and the levels of investment that go with them, of which we would otherwise be capable - and indeed which we might otherwise choose.

The FitzGerald (1993) National Saving report suggested responses to each of those specific aspects of the issue. As a means of approaching the question of the level of saving to which policy should aim if it could not establish the conditions for an optimal saving level to emerge automatically, the report looked primarily at what rate of saving would effectively remove the constraint on our economic growth posed by our present low saving rate. It asked what national saving rate should be aimed at to achieve sustained rates of economic growth at the levels (approaching 5 per cent a year) that appear feasible in other respects, assuming that well-understood structural reforms remove other constraints to growth.

In very broad terms, the National Saving report analysis showed that while any policies to lift saving must have some short- to medium-term cost in restraining growth in consumption, in the longer term the trade-off is attractive; sustained higher saving will make possible sustained higher growth and higher levels of potential consumption. The illustrative arithmetic runs approximately as follows: ${ }^{5}$

- achieving steady 5 per cent annual GDP growth can be slıown to require efficient investment at a rate of around 25 per cent of GDP; 6

cent. Findlay and Jones (1982) put the figure for Australia at 40 per cent, though Australian marginal tax rates have since been reduced.

${ }^{5}$ The precise ligures are drawn from the modelling undertaken (by the Economic Planning Advisory Council) for Chapter 3 of FitzGerald (1993), but very similar results have been obtained by other modellers: see, for example, Access Economics Monitor, February 1995, pp.3-4.

${ }^{6}$ Gross national investment has approached that level in recent years only at the cyclical peaks, in 1989-90 and during 1994-95; over the intervening four years it was around 20 per cent of GDP. 
- any policy for sustainable growth must not involve spiralling increases in external liabilities; that is, it must imply stabilisation of Australia's external debt to GDP ratios at some level in the relatively foreseeable future. This can be shown to imply that the current account deficit averages no more than about 3 per cent of GDP; and

- hence, a pragmatic goal for policy might be to lift national saving to 22 or 23 per cent of GDP by some combination of measures. ${ }^{7}$ That happens to have been the average of the past three decades.

While most economists would, I think, agree that those numbers describe an outcome that hangs together, there is some disagreement about the causality involved and about whether policies indeed exist that can achieve, on a sustained basis, the shift in both national saving and national investment that is described by it. I argue below that there are such policies; and indeed it could also be argued that of all the policies which may affect a country's growth performance, policies in this area are among those offering the clearest scope to influence growth outcomes. ${ }^{8}$

\section{Can a National Saving Policy Work?}

Quite clearly policy can engineer increases in particular forms of saving. A compulsory superannuation policy, coupled with reforms to ensure that the savings involved are in fact used for retirement income, can clearly achieve the specific objectives of increasing saving in that form and ultimately reducing the burden of age pension outlays on future taxpayers. Similarly, fiscal responsibility policies clearly can change government's own saving level, as demonstrated by New Zealand (see Scott, 1995; Albon, 1995). Again, we know that changing the structure of taxation can shift the pattern of saving. Indeed it is notorious that Australian saving patterns, and also patterns in some other OECD countries, are strongly distorted towards housing.

A dossier of facts presenting persuasive 'smoking gun' indications of distortion towards excessive investment in housing assembled by Dr Judith Yates was reported in an article by Ross Gittins in the Sydney Moning Herald of 10 November 1993. For example, the number of homes has in the post-war period increased very significantly laster than the population, the number of people per house falling from close to four in the late 1940 s to two-and-a-half in the early 1990 s. Over the past 20 years, the size of houses has increased substantially, the proportion with four or more rooms increasing from 13 to 19 per cent. This occurred even though population growth over that period was strongly skewed to single-person households,

\footnotetext{
${ }^{7}$ Saving fell below 16 per cent of GDP in 1991-92 and 1992-93; at the top of the recent cycle, in 1994 , it had recovered to only 18 per cent of GDP.

${ }^{8}$ See, for example, Dowick (1995). After reviewing determinauts of long-run growth across the board, he concluded (inter alia) that, particularly for Australia, 'most obviously we would expect an increase in savings and investment to increase growh' (1995:43).
} 
whose number rose 45 per cent over the ten years to 1991. Again, over the 1970 s and $1980 \mathrm{~s}$ the average floor space of new homes rose by about 44 per cent or from 130 square metres to 187 square metres, more than can be attributed to the change in the average number of rooms.

Houses have been increasingly capitalised in other ways, including in the quality of materials and the amount and quality of equipment. At the last census 9 per cent of homes were empty; and calculations of actual numbers of rooms per person relative to ratios typical at around the middle of the life cycle suggest that there is, in some sense, a total under-utilisation of the housing stock of several times that vacancy rate. As well, yields on housing have been driven significantly below those on other assets, indicating distortion of saving away from areas where higher returns are available.

Data for the period 1975-76 to 1991-92 examined in FitzGerald and Harper (1993) show an imputed rental yield of only 4 per cent and a real capital gain component of less than 2 per cent; equity investments in Australian business over that period earned a real pre-tax yield of over 10 per cent. FitzGerald and Harper (1993) presented evidence that our tax structure is deeply implicated in this distortion of saving towards housing. It can be inferred that social-security means testing is similarly implicated. None of these points, however, demonstrates on its own that the overall level of national saving would be affected, or that, if it were, it would lead to higher investment. We need to be confident that:

- any increase in public saving will in fact lead to increased national saving rather than being offset by changed private saving (this depends largely on whether such an increase is achieved through revenue or expenditure measures);

- policies towards categories of private saving will increase it in total rather than simply rearranging it, and will in turn increase national saving (that is, not be offset by changed public saving); and that

- any increase in national saving will in fact lead to increased national investment and higher growth.

\section{Will Increasing National Saving Lead to Higher National Investment?}

On the last of those issues, there is no controversy about the association between high saving rates and high investment rates. An exhibit presented in the National Saving report, for example, clearly shows this for the APEC economies (FitzGerald, 1993:5). Studies of this association, particularly in the Asian context, abound (see for example Young, 1992).

Yet controversy remains about the direction of causation. This is a complex issue to research, since it is clear that whichever the primary direction of causality is, there are time lags and feedbacks. For example, there are time lags in the adjustment of consumption patterns to higher growth, so that measures that increase the 
rate of growth will, at least for some period, have the effect of causing some increase, or further increase, in the rate of saving. Yet as growth settles at a higher rate, saving should fall: why sacrifice more consumption now as you become confident of faster advance in your future income?

There is no space here to review this literature in detail, but it has a long pedigree. One major strand begins with the famous paper by Feldstein and Horioka (1980), which demonstrated that capital is not perfectly internationally mobile and that higher domestic saving is almost everywhere associated with higher domestic investment. The long stream of research started by that paper lias confirmed those results:

. . ample research over the past few years has failed to reject the basic finding: if a country raises the national saving rate by a percentage point, most of the increase in saving is retained in the form of increased investment. (Dombusch, 1991:220)

Recent studies in this stream have used sophisticated econometric techniques to establish not only associations but also directions of causality. These studies do not remove all disagreement, but the weight of them, particularly the more comprehensive ones, supports the conclusion that the main causality is from saving to growth. Looking at the Asian evidence, across countries and over time, Nelson (1993:36-7) found that:

Results . . . suggest that about 65 per cent of an increase in domestic saving is reflected in higher investment. . . Asian data also suggest that aggregate saving can be raised by an increase in government saving. . . Overall, Asian data support the FitzGerald report's proposition on relationships between aggregate saving and the economy. Higher ratios of total saving to GDP are associated with higher investment ratios and higher government saving is associated with higher aggregate saving and a reduced current account deficit.

I believe that we can be confident, on the evidence, that policies which do succeed in lifting national saving will also lift national investment (and as well reduce the external deficit), leading to higher growth on a sustainable basis.

\section{Will Increased Government Saving Increase National Saving?}

The next step in the logic chain is to consider further the evidence for the proposition that lifting public saving will lead to increased uationa/saving. Here, in addition to Nelson (1993), supportive evidence exists. For example, Blundell-Wignall and Stevens (1992) show that movements in public saving are only partially offset by movements in private saving (and vice versa). Another econometric study across countries and over time by Hutchison (1992) concluded not only that the declines in government saving in many countries over the past two decades have been mainly 
responsible for the observed falls in national saving, but that the impact of government saving on national saving depends significantly on the particular composition of the expenditure/tax structure - which is consistent with the studies cited earlier of the deadweight costs of marginal taxation. Hutchison's results:

... indicate fairly high private saving offsets to government budget deficits . .. when they are caused by tax reductions. . . When government budget deficits are generated by an increase in expenditure rather than a reduction in taxes, however, [there is] little evidence of a private saving offset. Since almost all of the declining government saving over the past two decades is attributable to rising expenditure, [the] results suggest that the fall in national saving is mainly due to the deterioration in government finances. (Hutchison, 1992:48)

Hutchison's study is of considerable interest in that it points to more sophisticated policies going beyond simple rules of thumb, useful as they are, such as the rule that the budget should be balanced or in surplus on average over the business cycle. Apart from the finding that achieving the same budget deficit outcome by ineans of tax rather than by expenditure measures will produce quite different private saving responses (because of the stronger impacts of taxes on incentives), Hutchison points out that:

... calculations of this nature must also consider the contingent liabilities of government incurred through existing legislation (pensions, social security, health care and so on). Contingent liabilities are often unfunded, typically off-budget. (Hutchison, 1992:48)

One implication is that we need, as a sounder basis for fiscal responsibility policies, much better financial information on government's operations, ideally - as in New Zealand - the full accruing of costs and liabilities, period by period. And we need to recognise that tax increases and spending cuts will not be equivalent: the latter will have greater effect on national saving, because there will be a smaller offsetting change in private saving in response.

\section{Can Policy Change National Saving through Private Saving?}

The last, and perhaps most interesting, questions on which evidence is needed are whether public policy can aflect national saving through private saving, and whether it can do so through compulsion or through measures affecting the structure of incentives facing decisions about voluntary saving. As for compulsory saving measures, there is ample evidence that they not only affect the level of saving through the particular channel (whether it be Australia's Superamnuation Guarantee system or Singapore's Central Provident Fund) but that they have net effects both on aggregate private saving and on national saving, despite some offsetting reduction of other saving. 
An empirical examination of this issue by FitzGerald and Harper (1992) found that over the short to medium term the offset to increased Superannuation Guarantee saving could amount to 50 per cent, despite the fact that the consumption spending of many low- to middle-income households affected appears significantly constrained by their current income. More recently, a Treasury group (Tulip \& Stott, 1994) has examined the issue and concluded that the offset may be as small as 30 per ceilt. Harper and I were (and are) strongly of the view that whatever the offset is in the short to medium term, it is likely to rise significantly over the long term as people's superammuation balances rise. In any event, the evidence supports the proposition that compulsion $\mathrm{can}$ increase both total private and national saving, although the effect may wane over the very long run.

The more interesting issue is whether voluntary private saving, and through it national saving, can be increased through changed incentives, whether in social security and welfare means-testing arrangements or the tax system. This is a much canvassed issue, especially in the United States. The 'optimists' include those who have been most prominent in researcling the empirical evidence, including extensive time series/cross section data, on how households with access to the US taxdeferred saving schemes (IRAs and $401(\mathrm{~K})$ accounts ${ }^{9}$ ) differ in their saving from households without such access. These researchers have produced more and more persuasive findings, as the evidence available to them has accumulated, showing that households with access to these saving velhicles have significautly higher private savings than otherwise similar houselıolds ${ }^{10}$ (see for example Poterba, Venti \& Wise, 1993).

The sceptics in the US debate argue either that the evidence indicates (or does not rule out) mere rearrangement of the forms in which household saving is undertaken; or, if there are positive effects on private saving, that these are outweighed by the cost to public saving of the tax concessions. Engen, Gale and Scholz (1994) argue on these lines. Significantly, they concede that the evidence does now clearly show that access to IRAs, at least, raises the saving of the houseliolds concerned, although they dispute this for the $401(\mathrm{~K})$ vehicle. (A difficulty for this research is that dollar limits on access have recently been tightened, reducing considerably the number of households presented with an effective incentive at the margin. Clearly, for such schemes to achieve their policy purposes, access to them must either be unrestricted or leave the bulk of the population - at least middle, if not upper, income earners - with an effective incentive.)

The sceptics' major fallback argument is that the positive effect on private saving of these velicles, which they concede for IRAs at least, is outweighed by the public saving cost and that there is therefore 10 gain to national saving.

\footnotetext{
${ }^{9}$ Individual and employer sponsored retirement saving accounts respectively.

${ }^{10}$ Most policies to change the incentives for saving have both income and substitution effects; the evidence is that, at least for pure tax defenal schemes like the US ones, substitution effects dominate.
} 


\section{What Conclusions Does the Evidence Support?}

In my view, this debate about the US evidence leads to two main conclusions. First, it is now difficult to dispute the mounting evidence showing that households given access to taxed-deferred saving vehicles increase their private saving. Second, the fallback argument of the sceptics about the public saving offset is misconstrued. Since the US velhicles concerned are pure tax-deferral vehicles with no concession in the tax rates applying to withdrawals, it is not clear that, viewed in the proper time frame, there is necessarily any offset in public saving at all. Indeed, there is potentially a public saving gain once the measures are phased in. If we ignore the possibility of unlimited deferral (which can easily be prevented ${ }^{11}$ ) and the possibility that some savers might withdraw savings at a time when they may have moved into a lower tax bracket, ${ }^{12}$ it is clear that so long as additional savings earn returns better than the government's cost of borrowing, the government will collect a flow of taxes which is higher in the medium to long term and has a larger net present value at the outset than if the amount was taxed as income at the outset and spent. Any fund well invested for the long term will readily meet that condition.

The impact on government fillances of reforms to taxation designed to optimise incentives for saving must be viewed over the typical time frame of that saving. Government itself needs to set aside the 'short-termist' mindset. Surely, even a government facing a three-year electoral cycle could take the modestly extended medium-term view of its finances required to introduce such a scheme.

It is of course true that some saving is presently undertaken in forms which are highly taxed now (such as interest-bearing saving) and that it may be difficult, even with (say) restrictions on the minimum term of saving qualifying for tax deferral, to fully quarantine such existing saving from tax-deferred treatment. However, it is clear that most households already keep to a bare minimum the savings they hold in such forms. ${ }^{13}$ Attracting saving out of housing, the much larger flow and stock, is both positively desirable and presents 110 problem of revenue loss. Where these issues may arise (that is, for those savings forms that are heavily taxed), it seems nevertheless desirable to change to an expenditure taxation basis, even if some element of revenue is forgone thereby (which could in principle be made up by other adjustments without affecting its progressivity and so on). Since it is likely that revenue will, over time, increase in respect of both new saving and saving attracted out

\footnotetext{
11 For example, by deeming withdrawal on decease (or explicitly re-introducing death duties, at least in respect of tax-deferred savings); or, less controversially, by restricting deferral to, say, ten years for non-retirement saving, given that saving for major life-cycle purposes other than retirement appears typically to have horizons less than this.

12 It seems to me desirable that tax should be levied at rates reflecting the person's circumstances at the time.

${ }^{13}$ The available data on disuibution of assets give a strong impression that most households hold in financial forms (outside superannuation) only the minimum balances needed for immediate transactions-related purposes and contingencies: see Dilnot (1990).
} 
of housing, the overall result for public saving appears likely to be positive - after the phase-in period.

It is important to stress that adopting a policy of taxing saving on an expenditure basis would remove or greatly alleviate a major distortion to households' (and govemments') intertemporal choices, not introduce a new one. Not only is it, on the evidence, likely to increase saving overall, but it would also significantly reduce the present great distortion in the allocation of saving, namely, that towards housing. This distortion has pushed yields on such saving (perhaps two-thirds of total household accumulation) a long way below the returns available on investments in the wider economy. Desirable as good housing is, forgoing that difference in returns (at least 4 per cent a year ex post since the mid-1990s, on the basis of the data examined by FitzGerald and Harper, 1993) is a heavy cost.

Moreover, if compulsory saving for retirement is to have the desired net effect on saving overall - that is, if the offset in reduced other saving is not to rise to high levels - it is surely critical to present households, particularly middle-income households, with the maximum incentive that the economy can offer to maintain that other saving at high levels.

\section{National Saving and the 1995 Federal Budget}

National saving was a strong theme of Australia's 1995 federal budget. How does it measure up? Essentially there were three fronts on which saving policy needed to be advanced.

First, government's own saving needed to be restored to a sustained positive level - ideally by expenditure restraint rather than tax increases. If we bear in mind that government's cash accounting does not measure all accruing costs and liabilities, this indicates a benchmark for the presently measured recurrent budget surplus of the federal general government sector of around 2-3 per cent of GDP roughly where it was up to the mid-1970s (after adjustment for inter-level tranfers). Based on the economic scenario presented, the 1995 budget will go about half way to that, some years out, and do so predominantly by tax increases (most likely to be offset by changed private saving) rather than expenditure cuts. Moreover, the federal government appears to be reluctant to embrace the international trend whereby governments present meaningful operating accounts on an accruals basis and commit to a permanent regime of fiscal responsibility.

Second, the system of obligatory minimum self-provision for retirement needed to be completed and made effective. If we leave aside criticisms that can be made of the method of introduction (for example, about the over-riding of individuals' choice of fund for their own contributions out of their after-tax incomes), the proposals will, after a very long phasing-in period, achieve adequate retirement incomes and significantly reduce burdens on future taxpayers. ${ }^{14}$

\footnotetext{
${ }^{14}$ Indeed, unless the level of and eligibility for the age pension is reviewed some years in the future, provision will be excessive for the typical Australian: that is, it will provide a post-retirement purchasing power for beneficiaries greater than they had before - viz. the case of the person at 75 per cent of
} 
However, some critical issues remain to be addressed to ensure the effectiveness of the system: in particular, a more effective mesh with the pension means test, in order substantially to restrict double dipping; and a shift to ensuring that the bulk of benefits is taken in the form of an income stream rather than as lump sums.

Third, reforms were needed to the structure of incentives for voluntary saving (mainly through the tax system, but also the social security and welfare systems). The budget is silent on this, giving the impression that reform here has been rejected. If so, this is a great pity, since it means that, ultimately, the compulsory saving measures will have a more limited net effect on total household saving than desired, and the very powerful present distortions towards over-investment in housing and generally towards consumption rather than saving will remain.

We have made a good start towards a balanced saving policy, but we have a considerable way to go.

\section{References}

Albon, R. (1995), 'Fusuring Responsibility in Australian Budgets', Agenda 2(1): 17-26.

Andersen, P. \& D. Gruen (1995), 'Macroeconomic Policies and Growth', paper presented to a Reserve Bank of Australia Conference on Productivity and Growth, Sydney, July.

Blundell-Wignall, A. \& G. Stevens (1992), 'Fiscal Policy in Australia: Recent Developments and Current Issues', in Bank for Intennational Settlements, Cument Issues in Fiscal Policy and Their Implications for the Conduct of Monetary Policy, Basle.

Cox, J. (1994), 'National Savings and Fiscal Policy', Agenda 1(1): 25-32.

Diewert, E. \& D. Lawrence (1995), 'The Excess Burden of Taxation in New Zealand', Agenda 2(1): 27-34.

Dilnot, A. (1990), 'The Distribution and Composition of Personal Sector Wealth in Australia', Australian Economic Review 89 (1st Quarter): 33-40.

Dombush, R. (1991), 'Comment', pp.220-6 in B. Bemheim \& J. Shovelı (eds), Natioual Saving and Economic Performance, University of Chicago Press, Chicago.

Dowrick, S. (1995), 'Determinants of Long-Run Growh', paper presented to Reserve Bank of Australian Conference on Productivity and Growth, Sydney, July.

Edey, M., R. Foster \& I. Macfarlane (1991), 'The Role of Superannuation in the Financial Sector and in Aggregate Saving: A Review of Recent Trends', Reserve Bank of Australia, Sydney (Research Discussion Paper No. 9112).

Engen, E., W. Gale \& J. Scholz (1994), 'Do Saving Incentives Work?', Brookiugs Papers on Economic Activity 1: 85-179.

average weekly ordinary time earnings in Willis (1995:Chart 4). However, given that many people now in mid-career will not accrue full levels of provision under the new system before they retire, this is, for the time being, the right direction in which to err. 
Feldstein, M. \& C. Horioka (1980), 'Domestic Saving and Inteniational Capital Flows', Economic Jourual 90: 314-29.

Findlay, C. \& R. Jones (1982), 'The Marginal Costs of Australiau Income Taxation', Economic Record 58: 253-62.

FitzGerald, V. (1993), National Saving: A Report to the Treasurer, AGPS, Canberra.

\& I. Harper (1992), 'Super Preferred or "Level Playing Field"? Implications for Saving and the Financial System', Australian Tax Forum 9(2): 193-258.

\& I. Happer (1993), 'Taxation and the allocation of household saving: Further evidence for Australia', paper presented to the Fifth Melboume Money and Finance Conference, Baxter, 2627 November.

Freebaim, J., M. Poiter \& C. Walsh (1989), Savings and Productivity: Incentives for the 1.990s, Allen \& Unwin, Sydney.

Friedman, M. (1990), 'What Is the "Right" Amount of Saving?', Policy6 (Spring): 52-4.

Hutchison, M. (1992), 'Budget Policy and the Decline of National Saving Revisited', Bank for International Settlements, Basle (BIS Economic Papers No. 33).

Institute for Fiscal Studies (1978), The Structure and Reform of Direct Taxation (J. Meade, chair), Allen \& Unwin, London.

Nelson, E. (1993), 'Saving, Investment and Govennment Saving: Asian Evidence', paper presented to the Conference of Economists, Murdoch University, 28 September.

Poterba, J., S. Venti \& D. Wise (1993), 'Do 401(K) Contributions Crowd Out Other Personal Saving?', National Burcau of Economic Research, Cambridge, Mass. (NBER Working Paper No. 4391).

Scott, G. (1995), 'New Zealand's Fiscal Responsibility Act', Agenda 2(1): 3-16.

Sims, R. (1995), 'Assessing the 1995-96 Budget: Australia Must Choose betwecn Smaller Goven1ment and Broadening its Tax Base', Economic Papers 14(2): 67-82.

Tulip, P. \& D. Stott (1994), 'The Effect of Compulsory Superannuation on Private Saving', unpublished seminar paper, Department of the Treasury, Canberra, $13 \mathrm{July}$.

Willis, the Hon. R. (1995), Saving for Our Future, statement accompanying 1995 Federal Budget, AGPS, Cauberra.

Young, A. (1992), 'A Tale of Two Cities: Factor Accumulation and Teclnical Change in Hong Kong and Singapore', pp.13-63 in National Bureau of Economic Research, NBER Macroeconomics Amual 1992, Cambridge, Mass. 